\title{
Combined mitral valve replacement associated with the Bentall procedure, diaphragmatic hernia repair and reconstruction of the pectus excavatum in a 26-year-old patient with Marfan syndrome
}

\author{
Piotr Stępiński, Tomasz Stankowski, Sleiman Sebastian Aboul-Hassan, Anna Szymańska, \\ Jakub Marczak, Romuald Cichoń
}

Department of Cardiac Surgery, MEDINET Heart Centre Ltd., Wroclaw, Poland

Kardiochirurgia i Torakochirurgia Polska 2016; 13 (2): 135-139

\begin{abstract}
A 26-year-old man with Marfan syndrome was admitted as an emergency patient with ascending aorta aneurysm, severe mitral and aortic regurgitation, diaphragmatic hernia and pectus excavatum. After completion of diagnostics a combined surgical procedure was performed.
\end{abstract}

Key words: Marfan syndrome, aortic aneurysm, pectus excavatum.

\section{Introduction}

Marfan syndrome is a genetic disorder that affects the body's connective tissue. This disease is autosomal dominant and it is caused by a mutation in the FBN-1 gene [1]. Fibrillin-1 is a protein that in humans is encoded by the FBN-1 gene. The encoded protein is an extracellular matrix glycoprotein, which is essential for the formation of the elastic fibers and microfibrils, that provide strength and flexibility to the connective tissue. Normal fibrillin-1 protein contributes the binding activity of the transforming growth factor $\beta$ (TGF- $\beta$ ) protein in the connective tissue [2]. Transforming growth factor $\beta$ is a cytokine which affects the process of angiogenesis as well as synthesis and breakdown of the extracellular matrix proteins, and it regulates the apoptotic pathway. The production of abnormal fibrillin-1 protein in patients with Marfan syndrome causes the TGF- $\beta$ to circulate in an inactive state. This mutation results in production of abnormal elastic fibers, $\alpha$ collagen chains and ground substances of connective tissue [3]. The most severe complications in patients with Marfan syndrome are caused by defects in the tunica media of the blood vessels, which lead to the formation of aneurysms, mainly in the aorta [4]. The most common causes of death are aortic dissection and aortic rupture secondary to an aortic aneurysm. The most

\section{Streszczenie}

Mężczyzna 26-letni z zespołem Marfana został przyjęty na oddział kardiochirurgii w trybie pilnym z rozpoznaniem: tętniak aorty wstępującej, ciężka niedomykalność zastawki mitralnej i aortalnej, przepuklina rozworu przełykowego oraz klatka piersiowa lejkowata. Po dokonaniu szczegółowej diagnostyki przeprowadzono złożony zabieg naprawczy.

Słowa kluczowe: zespół Marfana, tętniak aorty, pectus excavatum.

serious signs and symptoms associated with Marfan syndrome involve the cardiovascular system and are caused by aortic regurgitation, mitral regurgitation, mitral valve prolapse, tricuspid valve prolapse and enlargement of the pulmonary trunk. In many patients with Marfan syndrome osteoarticular manifestations occur, such as pectus excavatum or pectus carinatum. Marfan syndrome can also seriously affect the eyes and vision, and it can also increase the tendency to get hernias and stretch marks [5].

\section{Case report}

A 26-year-old male patient with Marfan syndrome was admitted to the department of cardiology due to cardiac decompensation. Sudden cardiac arrest occurred due to electromechanical dissociation. The patient was success fully reanimated and was transferred to the intensive care unit (ICU). For 24 hours, therapeutic hypothermia $\left(33^{\circ} \mathrm{C}\right)$ was induced. On the third day, the patient was weaned from sedation and recovered his consciousness. Medical imaging procedures revealed enlarged aortic bulb $92 \mathrm{~mm}$ $\times 80 \mathrm{~mm}$, severe aortic and mitral regurgitation, and huge diaphragmatic hernia, where the hernial sac containing the stomach, duodenum and the colon was located in the right pleural cavity. The patient also had severe chest wall defor- 
mation - pectus excavatum (Fig. 1). On the $10^{\text {th }}$ day, the intubated patient was transferred to the department of cardiac surgery. The patient underwent a combined surgical procedure where the mitral valve, aortic valve and ascending aorta had to be replaced simultaneously with the surgical repair of the huge diaphragmatic hernia and pectus excavatum. Through sternal incision, the myocutaneous flaps were dissected and the severely deformed sternum with the ribs were exposed. The body of the sternum was then resected into two parts for the further reconstruction procedure. The rib cartilage of the deformed ribs was resected and a periosteal flap was formed, preserving the two internal mammary arteries. The extracorporeal circulation was established. The aorta was then clamped and Calafiore cardioplegia was given through the aortic root. Then, the right atrium was opened, and through the interatrial septum the left atrium was exposed. Then the mitral valve was replaced using a mechanical prosthesis $(33 \mathrm{~mm}$ ). The Bentall procedure was performed using a mechanical prosthesis (29 mm). The distal part of the conduit was anastomosed with the ascending aorta using a continuous 3/0-prolene suture reinforced with Teflon felt strips and tissue glue. During the reperfusion the right atrium was closed and the patient was weaned from cardiopulmonary bypass using catecholamines. Laparotomy through the bilateral subcostal (Chevron) incision was performed. The left lobe of the liver was freed from the inferior vena cava, and the hernial sac containing the stomach, duodenum and the colon was exposed. The stomach, duodenum and the transverse colon were pushed back to their proper anatomic position in the abdominal cavity (Fig. 2). The hernia was then repaired and the gastric fundus was fixed to the diaphragm. Recon-
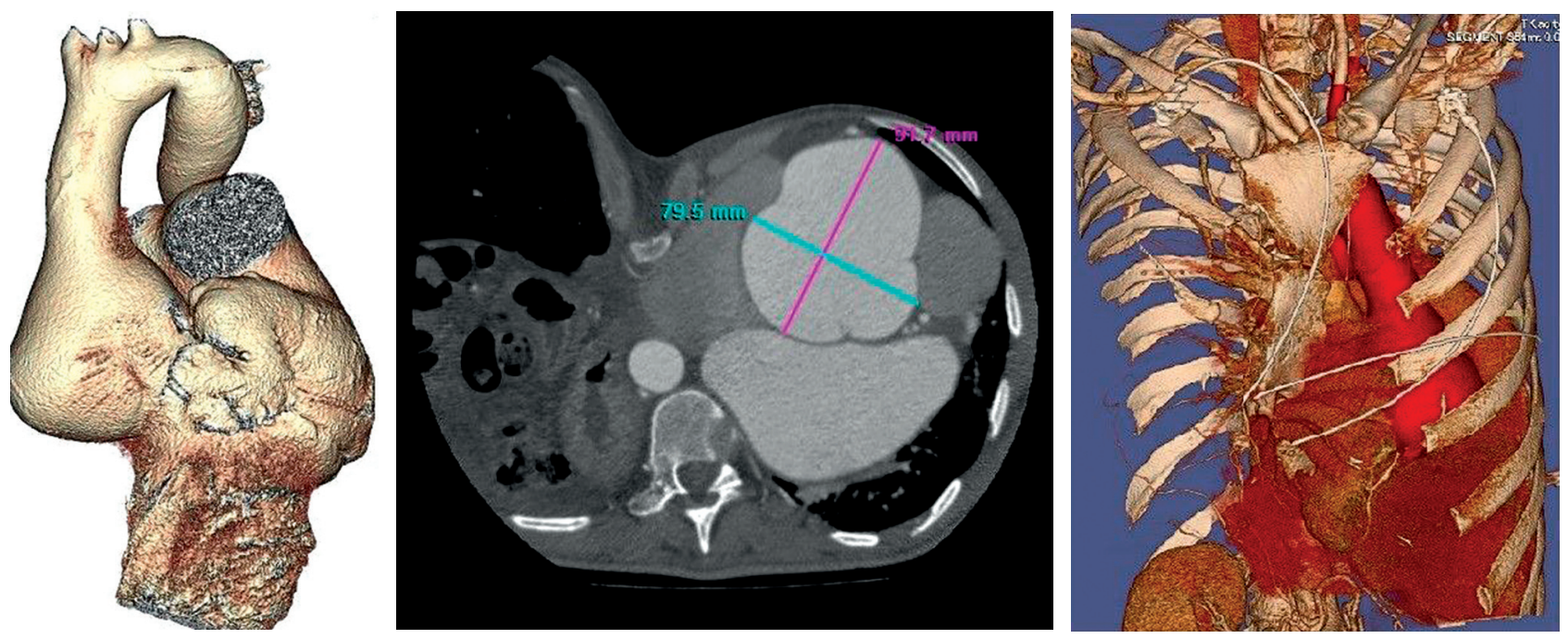

Fig. 1. Cardiac computed tomography angiography 10 days before the surgery

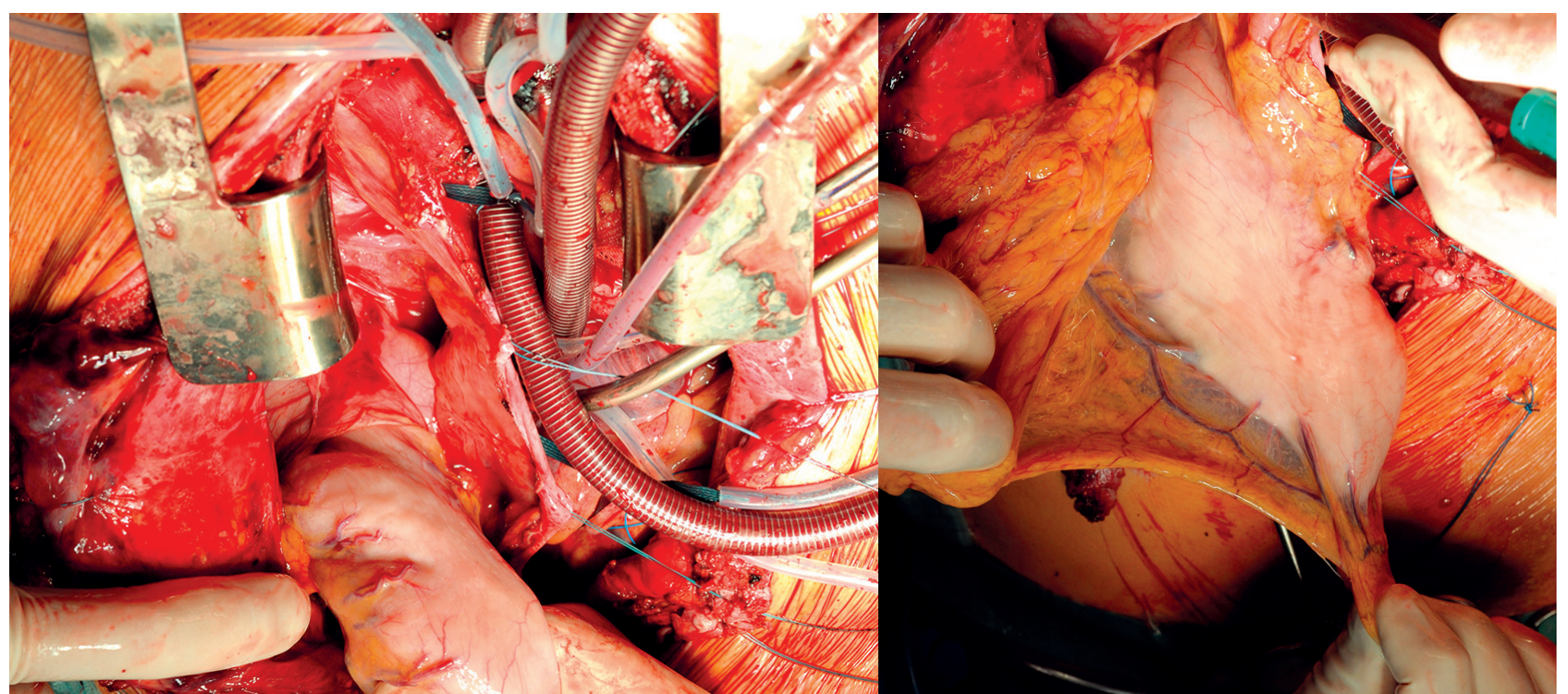

Fig. 2. Intraoperative picture - diaphragmatic hernia 


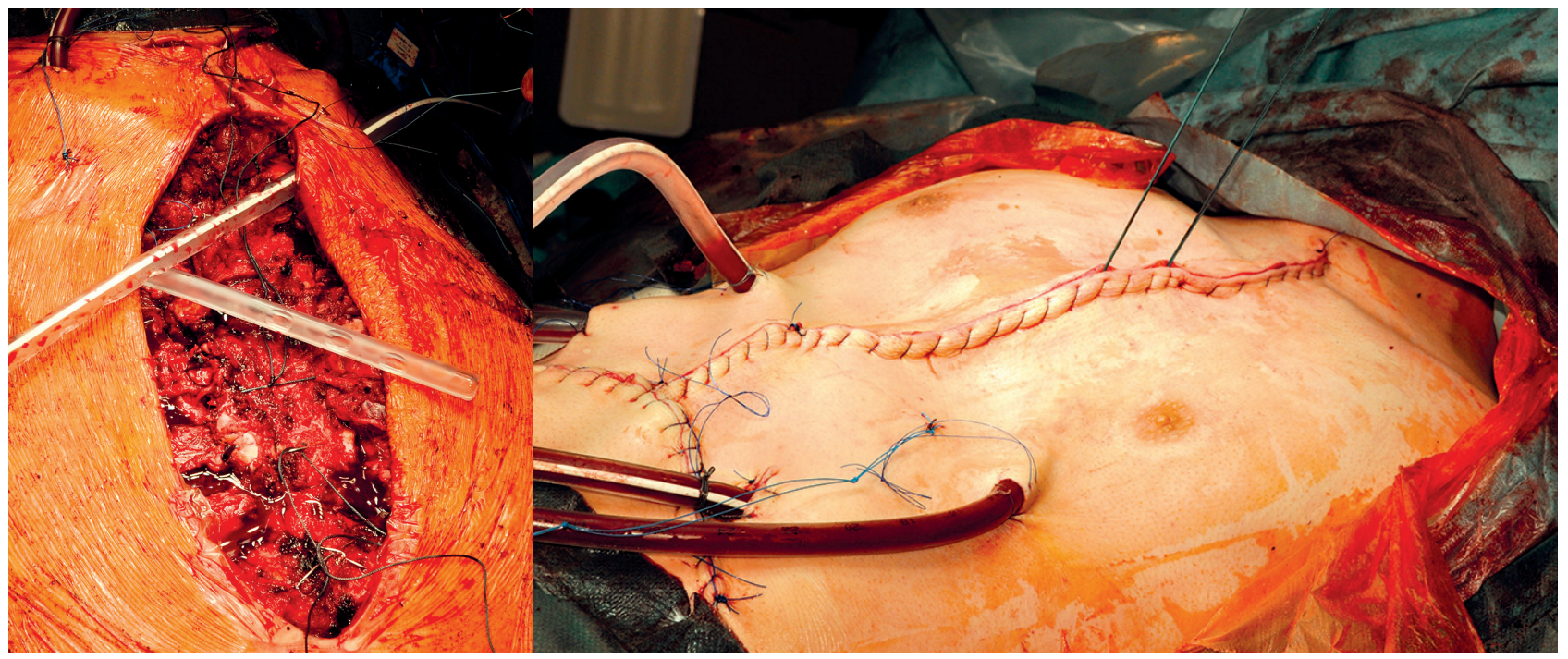

Fig. 3. Intraoperative picture - reconstructed thoracic cage

struction of the sternum was performed where the position of the manubrium was not changed, whereas the sternal corpus was inverted. The physiological shape of the chest wall was achieved using Ethibond Excel sutures and sternal wires (Fig. 3). The sternum was stabilized using an external chest frame. The surgery took $8 \mathrm{~h} 45 \mathrm{~min}$, cardiopulmonary bypass time $3 \mathrm{~h} 47 \mathrm{~min}$, aortic cross-clamp time $2 \mathrm{~h} 21 \mathrm{~min}$. Two days after the surgery, the patient was weaned from sedation and recovered his consciousness; however, extubation was possible on post-operative day six. After beginning oral nutrition the patient started coughing and vomiting. Upper gastrointestinal tract radiography revealed a bronchoesophageal fistula between the right main stem bronchus and the lower esophagus. The patient was transferred to the department of thoracic surgery. Bronchoscopy revealed pressure ulceration of the posterior tracheal wall with bronchoesophageal fistula, probably caused by endotracheal intubation (Fig. 4). During the next days, another bronchoscopy was performed and revealed a spontaneous closure of the bronchoesophageal fistula. Post-operative echocardiography revealed proper valvular prosthesis function. Cardiac computed tomography revealed a good result of the reconstruction of the pectus excavatum (Figs. 5, 6).

\section{Discussion}

The most serious pathologies in patients with Marfan syndrome are pathologies that affect the structure of the aorta and the function of the heart valves. Reports of combined operations in patients with Marfan syndrome are rare. Many studies have shown that these patients are often enrolled into staged procedures in order to manage their conditions [6-8]. In our case, it was decided to perform simultaneous surgery. In order to perform such complicated surgery, detailed preoperative diagnostic tests had to be done. In our case, detailed preoperative radiological and ultrasonographic diagnostics were performed in or-

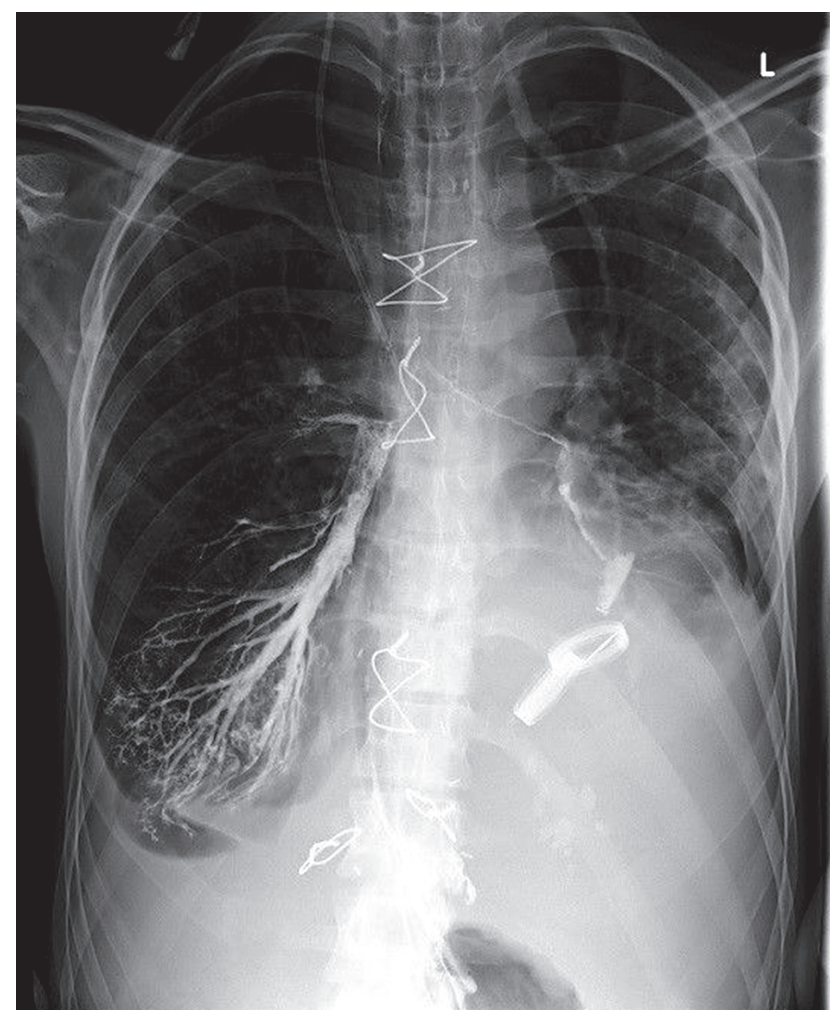

Fig. 4. Upper gastrointestinal tract radiography - bronchoesophageal fistula

der to evaluate possible defects among the thoracic and abdominal cavities. Combined simultaneous procedures provide many positive effects, especially in these patients. This complex procedure decreases the number of applications of general anesthesia to one. The development of diagnostic tests, especially in the field of radiology and ultrasonography, provides faster and wider access to rapid diagnostic tests and high-quality care. Consequently, better 


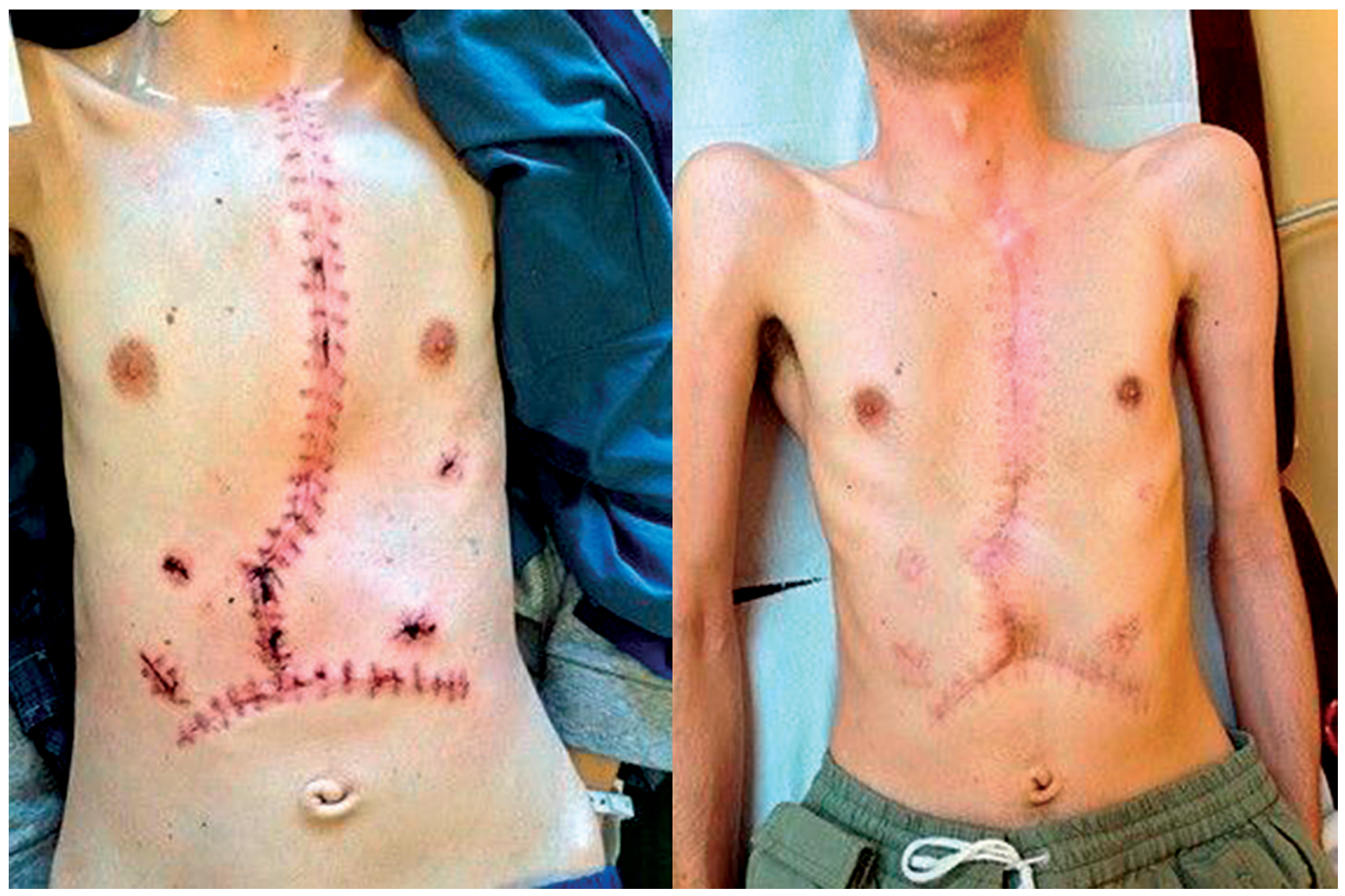

Fig. 5. Postoperative picture -2 weeks and 6 months after the surgery

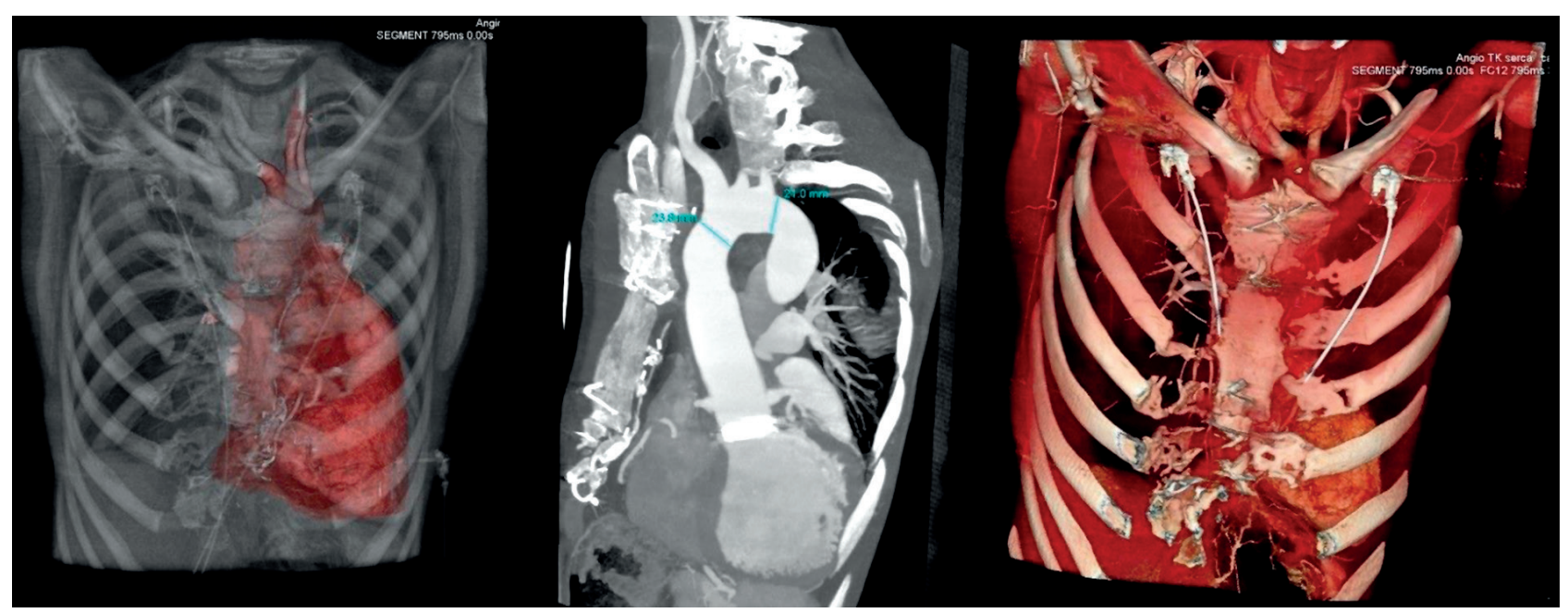

Fig. 6. Cardiac computed tomography angiography 12 weeks after the operation

health screening in asymptomatic patients with a positive family history is provided, and this can lead to an increase in health and life expectancy of patients with Marfan syndrome by over 30 years [5]. Such combined procedures that are performed to manage all conditions in these high-risk patients provide a lower amount of postoperative pain and injuries compared to patients undergoing staged procedures. On the other hand, a simultaneous operation shortens the duration and reduces the cost of hospitalization.

\section{Conclusions}

Combined surgery which included mitral valve replacement, the Bentall procedure, diaphragmatic hernia repair and reconstruction of the pectus excavatum is not a standard procedure, but it is very efficient and safe for such patients. Due to the fact that Marfan syndrome is associated with many disorders that affect different systems of the body, these patients always require an individual approach. 


\section{Disclosure}

Authors report no conflict of interest.

\section{References}

1. Dietz HC, Pyeritz RE. Mutations in the human gene for fibrillin-1 (FBN1) in the Marfan syndrome and related disorders. Hum Mol Genet 1995; 4 Spec No: $1799-1809$.

2. Dietz HC. New therapeutic approaches to Mendelian disorders. N Engl J Med 2010; 363: 852-863.

3. Blobe GC, Schiemann WP, Lodish HF. Role of transforming growth factor beta in human disease. N Engl J Med 2000; 342: 1350-1358.
4. Milewicz DM, Dietz HC, Miller DC. Treatment of aortic disease in patients with Marfan Sndrome. Circulation 2005; 111: e150-e157.

5. Jondeau G, Detaint D, Tubach F, Arnoult F, Milleron O, Raoux F, Delorme G, Mimoun L, Krapf L, Hamroun D, Beroud C, Roy C, Vahanian A, Boileau C. Aortic event rate in the Marfan population. A Cohort Study. Circulation 2012; 125: 226-232.

6. Chien HF, Chu SH. Simultaneous Bentall's procedure and sternal turnover in a patient with Marfan syndrome. J Cardiovasc Surg 1995; 36: 559-562.

7. Ichikawa S, Miyata Y, Usui M, Hirate Y, Ohmiya T, Ishihara T. Single-stage surgery for annulo aortic ectasia, Stanford type-A dissection and pectus excavatum in a patient with Marfan syndrome. Nippon Kyobu Geka Gakkai Zasshi 1996; 44: 575-579.

8. Javangula KC, Batchelor TJ, Jaber O, Watterson KG, Papagiannopoulos K. Combined severe pectus excavatum correction and aortic root replacement in Marfan syndrome. Ann Thorac Surg 2006; 81: 1913-1915. 